\title{
The Impact of Higher Education Loan System among Students from Low-Income Background in Tanzania
}

\author{
Watende Pius Nyoni \\ School of Public Administration, \\ Huazhong University of Science and Technology, Wuhan, China
}

Doi:10.19044/esj.2018.v14n28p39 URL:http://dx.doi.org/10.19044/esj.2018.v14n28p39

\begin{abstract}
In spite of the initiatives which have been taken by the government of Tanzania towards access to higher education for qualified students who came from low - income backgrounds, the studies and real situation reveal the reality of how this group of people has been denied to parity and fair for accessing higher education. Thus, Tanzania government has established Higher Education Students Loans Board with the Act No.9 of 2004 aiming at giving assistance to the students who got admission in universities, but came from low-income families with no financial strength to support their schooling. However, since its inception higher education loans board had failed to identify students from low-income background resulting in some students dropping out or postpone their studies as they look for other sources of funds. This article is qualitative in nature with the use of document analysis technique. The author uses relevant literature, officially published statistical data and various theoretical justifications for examining the impact of HE loan towards students from low-income background. The results of this study identified some challenges leading to a misallocation of fund to the needy students, application of Means Testing being one of them. Meanwhile, the author concludes with careful planning and effective use of means testing with a sustainable operational mechanism which will address the issue of parity and justice for the needy students in accessing higher education in Tanzania.
\end{abstract}

Keywords: Higher Education, Low-income Background, Students, Tanzania

\section{Introduction}

Higher education can be defined as the scope of knowledge and skills which have been imparted beyond the primary and secondary levels of education (Ishengoma, 2004). In Tanzania the structure of formal education and training system is built on 2-7-4-2-3+, denoting 2 years of pre-primary education, 7 years of primary education, 4 years of junior secondary or 
ordinary level, 2 years of senior secondary or advanced level and up to 3 or more years of higher education (Anangisye \& Fussy, 2014).

Higher education in Tanzania was established in 1961, as an affiliated college of the University of London having a faculty of law (Komba, 2017). This university stepped by Education for Self Reliance Policy (ESR) which was formulated in order to make an assessment of the insufficiencies and the unsuitability of the colonial education system. Besides, it sketches modifications and improvements required for bringing educational institutions near to the real life of Tanzanians. In 1963, the college became part of the University of East Africa, along with the Makerere University College in Uganda and Nairobi University College in Kenya. In July, 1970 the University of Dar-Es-Salaam was established to mark the beginning of a new epoch in the history of Tanzania's higher education (Sanyal \& Kinunda, 1977). Thus, the provision of education in higher education was free as it has been done in primary and secondary formal schooling regardless of race or religious beliefs ((Buchert, 1994).

In the past three decades, Tanzania experienced substantial expansion of higher education resulting in total, of 33 universities and 17 university colleges by the year 2015. Hence, Tanzania first president anticipated the students to contribute by serving the community for two years before joining to university (Rugambuka, 2008). This service later added one year of national service with the goal of preparing the person's assertiveness and social promise to the society after completing the studies (Mpiza, 2007).

\section{Purpose and Significance of the Study}

This paper mainly ought to examine the impact of the higher education loan system with regard to students from low-income background basing on its fairness and access. The results of this paper will depict relevant mechanism which can be used to make needy students have a fairy access to higher education. Besides, the mission of closing the gap between students from poor and rich families with regard to higher education would be met in an equitable manner through recommendation of this paper.

\section{Variables Matrix}

Table 1: Variables Matrix

\begin{tabular}{|c|c|c|c|c|}
\hline Objectives & Independent variables & Dependent variables & Measure of variables & Design \\
\hline $\begin{array}{l}\text { 1. To examine the impacts of HE loan on } \\
\text { students from low-income background }\end{array}$ & $\begin{array}{l}\text { Low-income } \\
\text { background }\end{array}$ & Higher educationloan & $\begin{array}{l}\text { Semi-structured questionnaire } \\
\text { for in-depth interview }\end{array}$ & Qualitative \\
\hline $\begin{array}{l}\text { 2. To develop sustainable HE loan scheme } \\
\text { for needy students }\end{array}$ & HE loan scheme & Needy students & $\begin{array}{l}\text { Good practice lessons from } \\
\text { literature for Strategic plan }\end{array}$ & Qualitative \\
\hline
\end{tabular}




\section{Review of the Related Literature}

This section provides the appropriate literature relating to the study paper. It focuses on relevant theories and empirical studies on the impact of higher education loan towards students from low-income background. It presents what is already known about higher education loan and the notion of cost sharing. Also, it gives a road map to identify the existing research gap which leads the need for writing this paper. The focus of these literatures is being justified by the way the issue of cost sharing in higher education has been set and the mode used to distribute the higher education loan. Thus, the knowledge gained from these reviews gives a blueprint to mark on "The Impact of Higher Education Loan System among Students from LowIncome Background in Tanzania".

\subsection{Theoretical Perspectives}

The formulation of theories in academic writing usually intends to explain, predict, and understand phenomena and, in many cases, to challenge and extend existing knowledge within the limits of critical bounding assumptions (Abend, 2008; Fligstein \& McAdam, 2014). Thus, theories in academic paper support a study topic by explaining why the research problem under study exists.

This paper has drawn the knowledge from Education for Self Reliance (ESR) strategy and Human Capital Theory (HCT) so as to relate the current situation on cost sharing through higher education loan with the existence of HCT and experiences occurred when ESR was in place.

Education for Self-Reliance (ESR) was formulated in order to make an assessment of the insufficiencies and the unsuitability of the colonial education system. Besides, it sketches modifications and improvements required for bringing educational institutions near to the real life of Tanzanians. The policy found no ground for many people to pay tax just to educate few citizens, though, was not meant for higher education (Orodho, 2014). Rather, secondary education which was provided purposely for people to live and serve in the country, particularly in villages and rural areas (ibid.). Nevertheless, Human Capital Theory seeks to explain the idea where people spend money, time and other resources for future financial and non-financial earnings but not for present gratifications (Gillies, 2011).

According to (Checchi, 2006) human capital is integrated in human beings, and cannot be resold relatively it can be developed mostly at the beginning of individual life, and its phase of gathering is determined by physiological factors, and it cannot be resold.

Yet, human capital in education investment applies to the society as a whole because the society benefits from increased productivity of educated workers (Woodhall, 1987). Throughout the world this is recognized by 
governments who pay some or all of the costs of education, and provide free or subsidized tuition in schools or higher education institutions. Thus governments usually provide social savings standard in the case of allocation of resources to levels of education and years of schooling. This is because human capital concerns with not only development of single individuals but the societies as whole (Paulsen, 2001).

Besides, there are a number of critics towards this theory. The opponents of this theory argue that, "education acts as a screening device, since it calls for a certificate, a diploma or any of its kind which allows a person to get well-paid jobs without direct upsetting their efficiency". Thus, awareness of high level of return on the individual's higher level of education has been one of the bases for the introduction of cost sharing with students in various universities of higher education. Likewise, HCT plays a vital role in evolving the connection between education and economic development of the country. With this theory on hand, this paper examines the impact of the higher education loan system with regard to students from low-income background basing on its fairness and access. Therefore, application of this theory expects the policy makers and actors in Tanzania reflect and review their cost sharing policy through higher education loan for the better allocation to the needy students particularly those from poor and low-income backgrounds.

\subsection{The Concept of Cost-Sharing}

In reference to this paper, cost sharing in higher education can be defined as a shift in the burden of higher education costs from being born completely or fundamentally by government or taxpayers, to be shared with parents and students" ((D Bruce Johnstone, 2003). According to (Teixeira, Johnstone, Rosa, \& Vossensteyn, 2006) cost sharing in higher education have been grouped into six categories namely; (1) Introduction of tuition fees where public higher education was formerly free, (2) sharp increases in tuition fees where public higher education tuition has already existed, (3) the imposition of user charges to recover the expenses of formerly subsidized food and accommodations, (4) reduction of student grants or scholarships, (5) an increase in the effective recovery of student loans and (6) the official encouragement of tuition-dependent private higher education sector where it did not exist to absorb some of the ever increasing higher education demand. Tanzania has adapted category (1), (3), and (6) of cost sharing in higher education.

\subsection{Cost-Sharing in Higher Education on Global Context}

Free higher education philosophy for qualified students has been practiced worldwide for many years, predominantly in Western Europe, Central and Eastern Europe, Russia and the nations of the Former-Soviet 
Union and Francophone Africa. Besides, financial, government hardships had led the cutoff of higher education support globally and increase costs to students and families in the form of tuition fee. However, the world is being challenged on how to design a well-organized and operational student aid podium that can offset any depressing effect that tuition fees have on the involvement of students from low-income background (Schendel \& McCowan, 2016).

In the late1980s and early 1990s the move towards cost sharing started whereby the World Bank (WB) and the International Monetary Fund (IMF) led tertiary and higher education reforms focusing on the funding and supervision of higher education. These reforms were experienced in variances by rich and poor countries, basing on levels of technological growth and diverse political settings (Puja, 2009); (D Bruce Johnstone, 2003). On the other hand, a report on student loan schemes in developing countries indicates that; In South Africa, the credit-to-GDP ratio amounted to $88 \%$ in 2009, much higher than that of Burkina Faso (15\%), Cameroon (23\%), Nigeria (26\%), Ghana (32\%), or Kenya (35\%) (D Bruce Johnstone \& Marcucci, 2010). It specifies a level of financial development close to that of other emerging countries such as Vietnam or Thailand (between $90 \%$ and $100 \%$, according to the IMF).

Meanwhile, the growing number of secondary leavers led strong pressure for unbiased extension of enrollment where university degrees were perceived as the primary means of economic advancement and social mobility. Moreover, universities were coping with the challenges of sustaining excellence in the face of speedy expansion, mainly as massification where there is an increase in absolute numbers of students and a snowballing variety of incoming students.

Likewise, China has made enormous steps in mounting access to higher education whereby over a span of less than 20 years, the number of students in tertiary education doubled that of the United States and became the largest body of tertiary education students in the world (Pan, 2013). Due to this massification, China shifted from a system of free tertiary education to a costsharing system though it transformed the demographics of students, thus changing parity.

Though, courtesy to the excellence of higher education is, consequently, vital in ensuring that access is meaningful for students and that institutions can make a positive contribution to society beyond the issuing of diplomas (Schendel \& McCowan, 2015).

\subsection{Implementation of Higher Education Loan in Tanzania}

Development of any nation depends much on education as it is simple to organize educated people to take charge in developmental matters than 
illiterate ones. As it has been stated in Human Capital Theory that, through education workers could raise production due to acquired knowledge and skills which in turn increase workers' income throughout their lifetime (Becker, 1994). As it has been revealed by (Carnoy, 2006) that, a modern country spends much of its resources in educating people, where's the invested resources have a positive impact on economic and social upshots in terms of growth, income distribution, social mobility, and the society's sense of wellbeing. The implication behind this concept relies on the fact that education determines welfare of a nation basing on micro-level and macro-conditions in the society.

However, it's evident from researches that; the educational achievement gap has a deep root in children's lives even before entering in schools. Socioeconomic variations like well-being and nutrition status, household settings that provide access to education related capabilities, mobility rates, and financial possessions can positively influence academic achievements (Laosa, 2005) cited in (Shaheen \& Gul, 2014).

According to (Eshetu, 2015) parents are responsible for their children's education, though this accountability can be affected by their financial status, parental educational background, profession and occupation. Students from low-income families are highly affected by this situation resulting in low performance and dropout (Evans, 2004). Therefore, in order to generate other means of revenue, cost sharing was introduced in higher education where students are expected to choose courses that have a greater potential to secure them jobs that offer higher remuneration upon completion and also reduce recurrence. In addition, universities are expected to be more responsive to society by introducing courses that meet market demands (D Bruce Johnstone, 2004b). Due to this perspective, parents' contribution towards their children's education is connected to the view that parents benefit indirectly through their children's education by having higher status and satisfaction (Ibid).

Besides, the implementations of cost sharing philosophy in most developing countries are being given to the high income group, though taxes are collected from the poor ((Psacharopoulos, Tan, \& Jimenez, 1986) cited in (McMahon, 2009). Due to the fact that cost sharing was favoring students from rich families, countries were encouraged to introduce targeted grants and/or loan schemes for students who cannot afford to pay the cost of higher education. Though, most countries that adopted loan schemes and/or targeted grants were unable to target the students in need of these funds as far as Tanzania is concerned (Mohamedbhai, 2014).

Meanwhile, the targeted grants were observed to be unsuccessful in most developing countries due to misallocation of funds to the targeted groups (D Bruce Johnstone, 2004a). That is, in most developing countries, it is rather difficult to assess the ability of parents or students to pay due to hidden income. 
Hence failure in the loan allocation to the needy students, which in turn may result in financial hardship resulting in low access, disparity and poor academic performance (Odebero, Bosire, Sang, Ngala, \& Ngware, 2007).

\section{Methods and Data Collection Tool}

The article is qualitative in nature with the use of document analysis technique. The author uses relevant literature, officially published statistical data and various theoretical justifications for examining the impact of HE loan towards students from low-income background. The paper was informed by the Human Capital Theory, which assumes that individuals and societies invest in higher education for assumption of yielding better benefits in the future (Memba \& Feng, 2016). The study is a qualitative research which has been defined extensively (Padgett, 2016) and (Denzin \& Giardina, 2016). The scholar's advocates for the effectiveness of qualitative research in this type of study are largely lying on its flexibility. In order to realize its objective, the study employed a historical research design, which (Wiersma \& Jurs, 2009) define as "systematic process of searching for the facts and then using the information to describe, analyze and interpret the past". The study employed the Document Analysis technique as a qualitative research method (Bowen, 2009). The document Analysis technique has been defined as a systematic procedure for reviewing or re-evaluating documents both printed and electronic computer-based and internet transmitted materials (Ibid.). Similar to other analytical methods in qualitative research, Document Analysis requires that data be examined and interpreted in order to elicit meaning, gain understanding, and develop empirical knowledge (Corbin \& Strauss, 2008). The author used the information from Tanzania Higher Education Students Loans Board website to assess its success by comparing the number of loan applicants and loan grantees for five years that means from 2012/2013 to $2016 / 2017$ in reference to the total enrollment list from the Tanzania Commission for Universities. Policies and procedural documents on loan delivery and refund were also reviewed for the better proof of effective application of the given procedure. In addition to that the author used officially published statistical data from the CitizenTznews@tz.nationmedia.com which analyses the trend of loan allocation for higher education students in the past five years with the mismatch of loan disbursed versus approved budget to examine the impact of $\mathrm{HE}$ loan towards students from low-income background. Here the author was interested to find the link between the guidelines and criteria for granting loans and if the eligibility criteria and guidelines for granting loan suits the Tanzanian students who came from low - income backgrounds.

Likewise, the issue of subjectivism was difficult to avoid as revealed by (Muijs, 2004) that, personal thoughts of the researcher may affect the study 
findings and lead to bias. Taking this into high consideration that I am working with the Ministry of Education, Science and Technology under the Higher Education Department I didn't include my personal understanding in analyzing the paper's findings, rather I applied the experience gained in the office when attending cases related to the paper topic to get stance on how the government can handle the issue of HE loans support towards qualified Tanzanian needy students. Therefore, during review of some literature, officially published statistical data and various theoretical justifications I changed my mind-set as if I am not familiar with the studied topic in order for data to speak for themselves and expose the burdens facing university students from lowincome families once they fail to get financial support from Higher Education Student's Loans Board.

\section{Findings and Discussion}

\subsection{Loan for Students from Lower-Income Background}

Tanzania government has established loan scheme as a strategy to support students who qualifies for higher education, but due to financial difficulties they could not have access to study. Under the cost sharing policy, students from low-income families through government loan or grant could pursue university studies, like those from wealthier families (cha-cha, 2004). Likewise, the mission for supporting needy students has also been emphasized by the World Bank with regard to the higher education reform that; cost sharing should be implemented in equal basis through the student loan program so as to be available to those who need to pay for their schooling (D Bruce Johnstone, 2004b).

Moreover, the World Bank's stance is revealed by (Checchi, 2006) that, students from poor backgrounds should be supported by loan to pursue higher education studies without looking on their poverty basis but they will repay in future.

However, the procedure for allocating loan to students who came from poor financial background in Tanzania is not well organized resulting to debate for unfair distribution. This situation has been witnessed by Dr. X of one big government university in the country that;

"......another mistake is allowing children of senior government officials and business persons to access loans. This led to needy students missing out considering that some of them are not pursuing the priority courses,"

Underlying to the above statement, a 21years old student boy who was enrolled in a bachelor degree in accredited public university was forced to postpone his studies after the Higher Education Students Loans Board delayed disbursing funds as he fought appeals against its negative response, forcing him to miss a number of exams. Empathizing with the situation, he said; 
“..... I went to public schools; my parents who live in a certain village in this country are very poor. I was puzzled why I didn't get the loan in the first batch," ..... but by the time the loan was approved and released in February 2017, I had already missed the first semester final exam that my colleagues sat in January. I decided to postpone my studies to next year......,",

Therefore, this situation could not leave unchecked, rather stakeholders should sit together to plan a new model for cost-sharing in higher education, supporting and the situation can be addressed if the government tightens the loan recovery system.

\subsection{Means testing}

The application for means testing as the best technique towards equity during the loan allocation process has triggered a discussion on whether it has a positive impact on students who need support of loan for their studies from poor families or not. This doubt has been built on the culture and experience that in Tanzania there are scarce or unknown data on family income status that fails the operation of means testing (Ishengoma, 2004). This fact is also exposed by a senior officer who works with HESLB for students who botched to get loans that;

"......there are some needy students who failed to get loans because they didn't bring the required documents to prove that requires priority and others were rejected because they used fake documents to justify their needs...."

Thus, in order for means testing to work properly, there must be verifiable measures of family income and family assets (Marcucci \& Johnstone, 2003). Nevertheless, the better use of means testing results to the acceptance of cost sharing. Therefore, the effective use of means testing as suggested by (D Bruce Johnstone, 2004c) may lead to parity and balance on loan allocation, especially to the needy students as far as our discussion is concerned.

\subsection{Loan Allocation to Higher Education Students in the past Five Years 2012/2013-2016/2017}

The government of Tanzania has made efforts to increase the number of loan beneficiaries to 124,711 in the year 2016/2017. But it has been dealt a major shock by a substantial flow on the list of those missing out on state education funding, the worst case in the past five years. At the same time, the number of students applying for the loans has over the years increasingly bettered the Tanzania Universities Commission (TCU) annual admission figures. By and large, it is a sign of mounting fear of government support by 
needy Tanzanians who are looking for higher education. See fig. 1 below which shows the trend of five years' loan allocation.

*As of March 31, 2017 w First year students admitted = HESLB loan applicants

= students received loan from HESLB
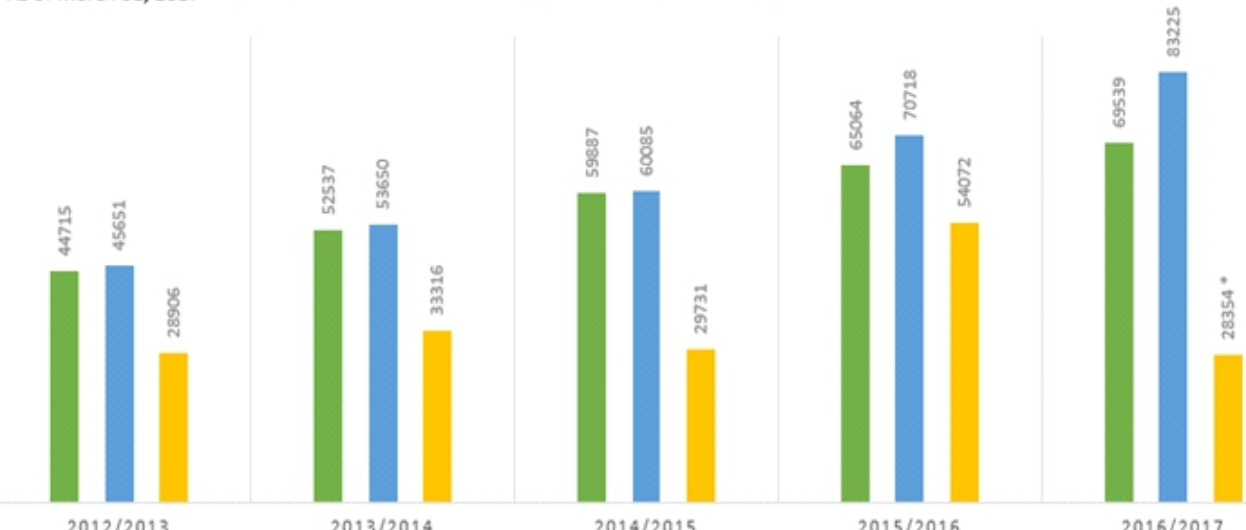

Figure 1: The Trend of Loan Allocation to Higher Education Students in the Past Five Years Source: Higher Education Students Loans Board (HESLB) and Tanzania Commission for Universities

In reference to the above figure and analysis done by a researcher through data from HESLB, it denotes that, over a five-year period, by March 31, 2017; two out of three students who applied for the loan at 2016/17 have missed it. Meanwhile, HESLB is intimidated by the outpouring in university enrollment to the extent that it is also increasingly failing to meet the loan demand, even among the needy students who are the intended beneficiaries. Statistics show that up to 2012/13, the number of students accessing loans increased almost every year, with an average of three out of 10 applicants missing out the loan.

Though the fifth phase government set a record in its first year when the number of first-year students who got HESLB loans almost doubled from 29,731 in the year $2014 / 2015$ to 54,072 in $2015 / 16$. But that is likely to be outshined by the new certainties as it appears that the number of loan beneficiaries sharply dropped in the 2016/17 academic year from 54,072 in 2016 to 28,354 by March 31, 2017. And in all the five years under review, it has emerged that the number of first year students admitted to universities and colleges through the Tanzania Commission for Universities was less than those who applied for HESLB loans

\subsection{Mismatch between Approved Budget versus Disbursed Budget}

Due to the increased enrollment in higher education, universities, resulting in the increase in secondary schools following the establishment of ward secondary schools and other emerging private secondary schools, has led to an increase in demand for higher education. In the year 2016/2017 Higher Education Students Loans Board was intimidated by the flow in university 
admission, which mirrored the failure to meet the loan need, especially for the students from low-income background who are the envisioned beneficiaries. The proofs given by the Citizen show the major setback by the government where's there were mismatched between the approved budget versus disbursed budget for the year 2014/2015-2016/2017 resulting to the increase number of students who missed the loan nastiest while disbursed budget for the year 2015/2016 was higher than approved budget something which is good for the loan beneficiary but for government it might not meet some targets of the development projects. Besides, it is a sign of mounting fear of government support by needy Tanzanians who are looking for tertiary education. Fig. 2 hereunder accounts for the five years approved budget versus disbursed budget.

Referring to the figure below a researcher has learnt that, the government has scarce resources, challenging priorities and has a deficiency of alternative sources of education funding, which hinder the accomplishment on the dreams of many students who come from a low - income background, hoping on higher education as the only future investment for alleviating poverty.
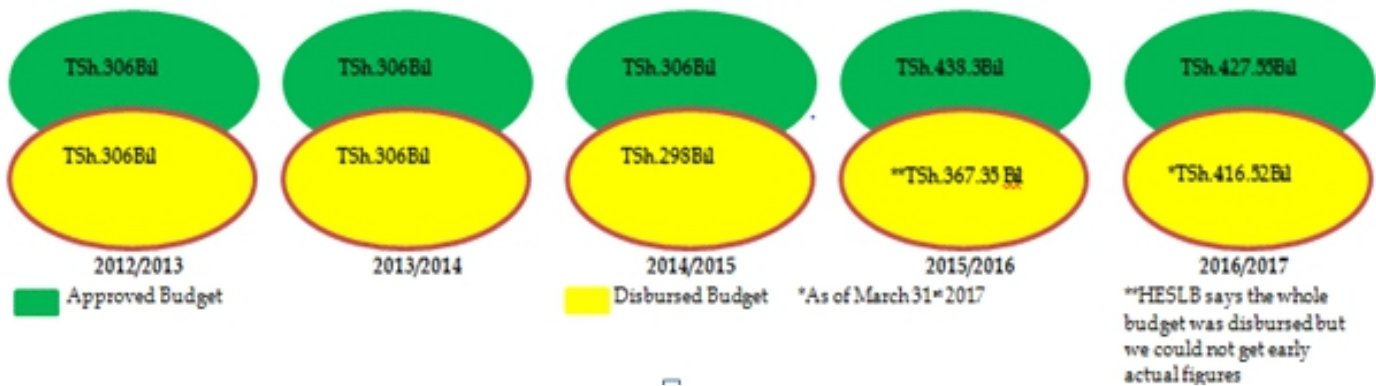

Figure 2: HESLB Fund disbursement for the past five years: Approved budget vs. Disbursed budget Source: Tanzania Higher Education Students Loans Board (HESLB)

Apart from that, there were increases in the number of student loan applicants from 49,914 in year $2012 / 2013$ to 55,033 , and 62,359 in year 2013/2014 and 2014/2015 respectively. According to HESLB, 83,255 students applied for loans, almost twice the number of 2012/13 applicants. Likewise, 7 students out of 10 who applied for higher education loan in 2016/2017 academic year have missed it. Shockingly, the number of loan beneficiaries in one public university dropped from 23,786 to $2015 / 2016$ to 16,758 in 2016/2017 academic year, while 1,105 students postponed their studies due to financial reasons in another big public university in the year 2016/2017. However, the government utters the funds are for needy Tanzanian students only though they are ones who mostly miss the loan and; hence, it is not given 
that everyone who applies for the loans gets them. The government insists that education financing is exclusively the responsibility of parents and guardians.

\subsection{China's Experience in Supporting Tertiary Students from Disadvantaged Background}

In 30 years China shifted from a government-funded, free tertiary education system to a cost-sharing system. This transformation goes hand in hand with the shift from a planned economy to the socialist market economy and rapid economic progress resulting in the changes in the structure of education cost together with the state resource distribution. China economic growth had a great impact on social variations in terms of income between rural and urban as well as education levels of professionals and urban working class (Dollar, 2007). Due to this growth there was also the decline of higher education reforms inform of access which strengthened social and economic inequality among economically and culturally disadvantaged groups.

However, this situation was seriously handled by reviewing the higher education policy in order to bridge the gap and give access to higher education for qualified students from four disadvantaged groups, namely; lower-income families, women, minorities and people living with disabilities.

\subsubsection{Students from lower-income families}

It is evident from the literature that, students who are qualified for tertiary education, but came from poor family background are facing economic hardships towards their right to access higher studies. Some students from lowincome families aspiring for $\mathrm{HE}$ studies often face financial difficulties, which limit their academic performance. For example, engaging in paid work while schooling in order to cover some costs where in turn reduces the time and energy to concentrate with studies. (Jing, Sun \& Liu, 2010).

Likewise, the introduction of cost sharing in higher education has largely reduced the percentage of enrollment for students from low-income families, though the ration for students from wealthier families increased (Yang, 2004). It has also been revealed that, students from farmers' and workers' families accounted for $45.2 \%$ (20.2\% and $25 \%$, respectively) of the total enrollment in 8 tertiary education institutions in Beijing in 1980, falling to $21 \%$ by 1990 (Xia, Wang, Do, \& Qin, 2014). These facts have been demonstrated in the figure 3 below on the distribution of tertiary students among various social groups. 

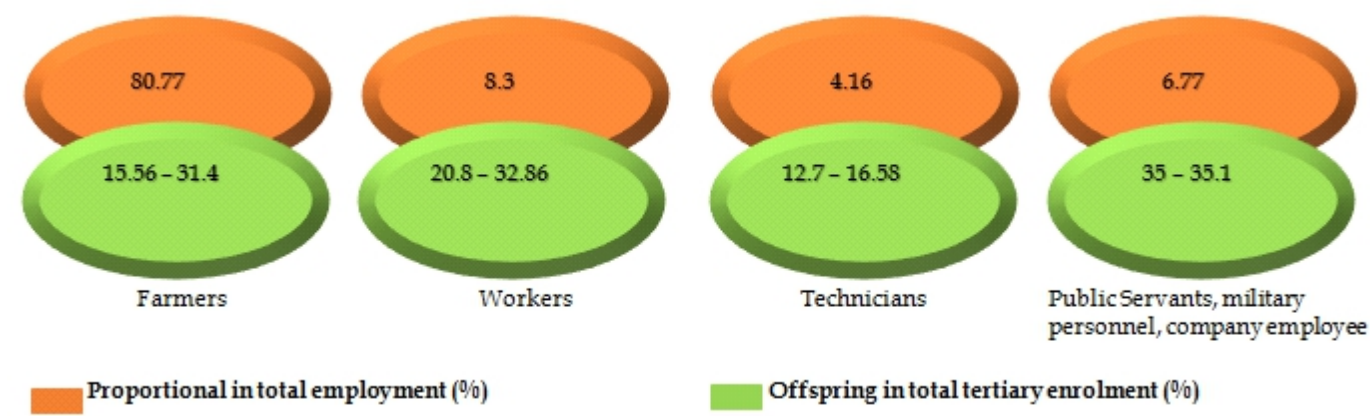

Figure 3: The percentage of offspring as tertiary students among various parental livelihood groups

Source: Li, W. (2008), Zhongguo Gaodeng Jiaoyu Ruxue Jihui de Gongpingxing Yanjiu [The Equity of the Entrance to the China's Higher Education], Perking University Press, Beijing. P. 104

Following the end of Peoples Grants and people's scholarships in the year 1986, the government in 1987 established a new strategy for supporting the needy students, which was controlled by scholarships and loan aids (Yan $\&$ Yudong, 2003). Nevertheless, at the start of the $21^{\text {st }}$ century the government provided different student assistance schemes with five components basing on public loan funds, commercial banks and grants (Wang et al., 2011). Thus, three out of five mechanisms were set for students from low income families to support their higher education schooling.

Meanwhile, a fund for the needy students were categorized in the form of loans, including commercial and public loans where's public loans was issued by the state targeting students from low-income families to complete their higher education. There were also programs like teaching, research, administration posts or other logistics which were being offered by HEIs for students from low-income families.

Similar to that, there was a Means-tested grant which was allocated by the central and local governments to support students with financial difficulties, including interim and regular grants for living costs. Additionally, students who were enrolled for the special programs, those from low-income families and the ones who intended to work in remote areas after graduation were being supported through tuition exemptions. Besides,

\subsubsection{Students from minority groups}

Since the year 1950, China government has established fourteen higher education institutions targeting students from minority groups like non-Han Chinese. The specialties for different programs in regular institutions depended on the students themselves on whether they opt to study special programs for minority students or regular programs. However, education reform in china went hand in hand with special strategies like affirmative action which aimed at improving access to tertiary education for students from minority groups. 
These efforts towards minority students led to the increase in percentage from $0.93 \%$ in 1950 to about $6 \%$ in the late 1980 s, and maintained the same level until 2009 as shown in figure 4 below:

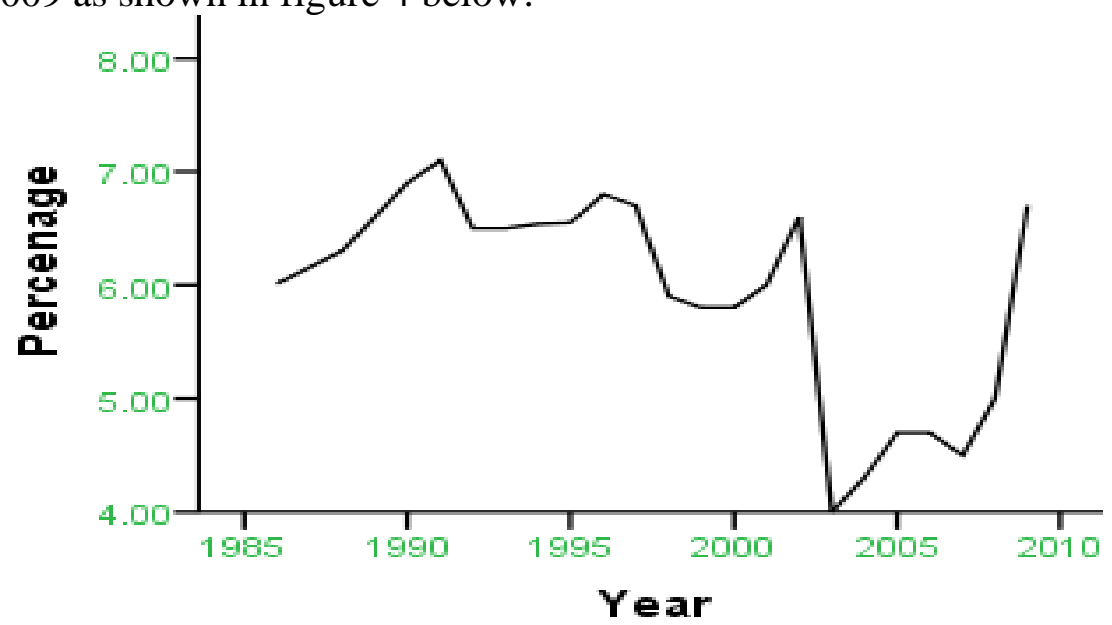

Figure 4: Share of minority students, as a percentage of the total enrollment (1986 2009) Source: Development and Planning Division, Education Department (2010), Educational Statistical Yearbook of China, People's Education Press, Beijing

\subsubsection{The percentage of minority students}

Underlying to the share which were given to the minority students, China government through the 1981 policy document enforced the fairness in enrollment by looking at the ratio of minority applicants in relation to the total number of the candidates applying for tertiary education not to be less than the total minority population mandated. Figure 5 below shows the proportion of minority students against the proportion of minority population from 19532009.

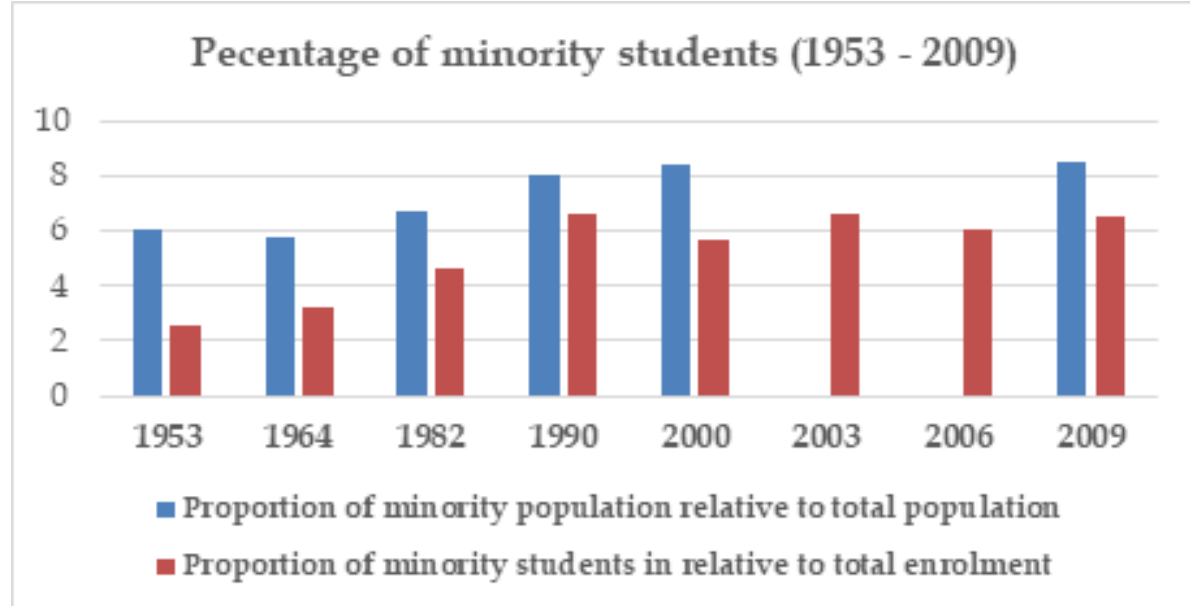

Figure 5: Percentage of minority students (1953 - 2009)

Source: Liu, E. (2010), "Dazhonghua shifa xia shaoshu minzu gaodeng jiaoyu ruxue jihui yanjiu” 
In fact, the figure above demonstrates the rise of minority students in terms of percentage while staying unchanging since the turn of the century in spite of a slight drop that occurred after the introduction of the universal feepaying system in 1997.

\subsubsection{Students with disabilities}

Provision of education with students having disability of any kind in China was also considered in a very special and unique way. Thus, students living with disabilities accessed programs in three ways, namely; special education programs in regular higher education institutions; separate departments or schools within the regular higher education institutions; and stand-alone tertiary special education institutions (Fogel, 2010).

By 2010, 7.674 people living with disabilities were admitted into regular tertiary education institutions and 1.057 entered special education colleges (Hampton \& Xiao, 2009). Due to this strategy the number of people living with disabilities in China totaled 82.69 million, of which 0.94 million has tertiary education attainment, equivalent to $1.13 \%$ of the total, which is much lower than the national average for able-bodied Chinese of $5.18 \%$.

However, China higher education support experience towards students from disadvantaged minority groups fluctuated between 2000 and 2010, illustrating that in several years of the decade growth rates of subsidy expenditures were not aligned to reach the majority of the students from disadvantaged groups. This situation advocates for allocation problems versus inadequate government budgetary support resulting in chaos for students from extremely poor families who accounted to 1.66 million (Shan et al., 2011).

\section{Conclusion and Recommendations \\ 6.1 Conclusion}

Focusing on the detailed discussion on the Impact of Higher Education Loan System among Students from Low-Income Background in Tanzania, this paper observed serious deficiency of financial support facing needy students who qualifies for higher education studies. The facts gathered depicted negative allegations on the matters regarding fairness and parity in accessing higher education. It has also been reflected that, the government support through higher education loan for students from low socio-economic background proved failure to a certain percent due to poor mechanism of applying the means testing for identifying the needy students resulting to many of them miss the loan. Nevertheless, the world is also facing alike financial pressure for facilitating higher education schemes in terms of direct and indirect costs like tuition fees, books, and living expenses and cases of supporting some students from low-income background for the sake of ensuring equality of opportunity, equity and social justice (Woodhall, 2002). 
In contrast, Tanzania efforts to support higher education for qualified students from poor families seem to be improperly planed from the beginning, hence misallocation of loan leading to disparity and access towards higher education. Hence, there is the need for careful planning and effective use of means testing with a sustainable operational mechanism which will address the issue of parity and justice for the needy students in accessing higher education as far as Tanzania is concerned.

\subsection{Recommendations}

In reference to what have been observed in this research paper, the following sustainable mechanism ought to be useful if could be taken into practice.

- Operational policies and guidelines should be formulated or reviewed in order to identify students from low-income background to get government support through loan basis for accessing higher education.

- Meanwhile, bottom-up approach should be applied when involving stakeholders during formulation, implementation and evaluation of educational policies. By so doing, people at the grassroots level will have an opportunity to determine their priorities and needs and include them in the educational policies and plans.

- Means testing should be reputable and reinforced. Local government authorities could team up with HESLB for the purpose of easy identification of needy students from their original places and know exactly the financial status of their families.

- The government through HESLB should look at other countries' experiences and good lessons which can guide future modification of allocating loan to the needy qualified student. Referring to the Mexican government, higher education needy students who are academically qualified, but they're financially poor are being supported first rather than their institutions which is being termed as demand-side financing (Donald Bruce Johnstone, 2006). This could be done in the area of governance and accountability.

- Likewise, Tanzania could also learn from China who developed student loan schemes as a part of the student aid package associated with the introduction of tuition at all public universities in the year1997. In china, there are good numbers of universities which provide interestfree loan schemes with funds from central government and local authorities, to help students, specifically the ones from low-income families to cover higher education costs. 


\section{Acknowledgments}

I am extremely grateful to my supervisor, Professor Chen He for her professional guidance and valuable advice towards my studies. Her consideration and encouragement have inspired me to put my best efforts in my academic life. She taught me how to manage my time, prioritize urgent tasks and she is always available for meetings to assess my progress.

Professor Chen mentored me via our cherished discussions and punctual emails. When I sent her my work, specifically this research paper I would often receive feedback within a week's time. Her strong work ethics and commitments to graduate students truly benefited me a lot. Thank you so much Professor for being a role model to me.

\section{References :}

1. Abend, Gabriel. (2008). The meaning of 'theory'. Sociological Theory, 26 (2), 173-199.

2. Anangisye, William AL, \& Fussy, Daniel. (2014). Tanzania: Revisiting eastern and central African education systems. Education in East and Central Africa, 16, 373.

3. Becker, Gary S. (1994). Human capital revisited Human Capital: A Theoretical and Empirical Analysis with Special Reference to Education (3rd Edition) (pp. 15-28): The university of Chicago press.

4. Bowen, Glenn A. (2009). Document analysis as a qualitative research method. Qualitative research journal, 9 (2), 27-40.

5. Buchert, Lene. (1994). Education in the Development of Tanzania, 1919-90: James Currey Publishers.

6. Carnoy, Martin. (2006). Higher education and economic development: India, China, and the 21st century. Paper presented at the Pan Asia Conference: Focus on Economic Challenges, Stanford Center for International Development, Stanford University, Palo Alto, CA, May.

7. Chacha, Nyaigotti Chacha. (2004). Reforming higher education in Kenya: challenges, lessons and opportunities. Paper presented at the State University of New York workshop with the Parliamentary Committee on Education, Science and Technology, Naivasha, Kenya.

8. Checchi, Daniele. (2006). The economics of education: Human capital, family background and inequality: Cambridge University Press.

9. Corbin, Juliet, \& Strauss, Anselm. (2008). Basics of qualitative research: Techniques and procedures for developing grounded theory.

10. Denzin, Norman K, \& Giardina, Michael D. (2016). Introduction Qualitative Inquiry - Past, Present, and Future (pp. 9-38): Routledge.

11. Dollar, David. (2007). Poverty, inequality, and social disparities during China's economic reform. 
12. Eshetu, Amogne Asfaw. (2015). Parental socio-economic status as a determinant factor of academic performance of students in regional examination: A case of Dessie town, Ethiopia. African educational research journal, 3 (4), 221-229.

13. Evans, Gary W. (2004). The environment of childhood poverty. American psychologist, 59 (2), 77.

14. Fligstein, Neil, \& McAdam, Doug. (2014). The field of theory. Contemporary Sociology, 43 (3), 315-318.

15. Fogel, Robert W. (2010). Why China is likely to achieve its growth objectives Investing In Human Capital For Economic Development In China (pp. 3-18): World Scientific.

16. Gillies, Donald. (2011). State education as high-yield investment: Human capital theory in European policy discourse. Journal of Pedagogy/Pedagogický casopis, 2 (2), 224-245.

17. Hampton, Nan Zhang, \& Xiao, Fei. (2009). Traditional Chinese values and attitudes of Chinese university students toward people with intellectual disabilities. International Journal of Disability, Development and Education, 56 (3), 247-261.

18. Ishengoma, M Johnson. (2004). Cost-sharing in higher education in Tanzania: Fact or fiction? Journal of Higher Education in Africa/Revue de l'enseignement supérieur en Afrique, 101-133.

19. Johnstone, D Bruce. (2003). Cost sharing in higher education: Tuition, financial assistance, and accessibility in a comparative perspective. Sociologický časopis/Czech Sociological Review, 351-374.

20. Johnstone, D Bruce. (2004a). Cost-sharing and equity in higher education: Implications of income contingent loans Markets in Higher Education (pp. 37-59): Springer.

21. Johnstone, D Bruce. (2004b). The economics and politics of cost sharing in higher education: comparative perspectives. Economics of education review, 23 (4), 403-410.

22. Johnstone, D Bruce. (2004c). Higher education finance and accessibility: Tuition fees and student loans in sub-Saharan Africa. Journal of Higher Education in Africa/Revue de l'enseignement supérieur en Afrique, 11-36.

23. Johnstone, D Bruce, \& Marcucci, Pamela N. (2010). Financing higher education worldwide: Who pays? Who should pay? : JHU Press.

24. Johnstone, Donald Bruce. (2006). Financing higher education: Costsharing in international perspective: Boston College Center for International Higher Education.

25. Komba, Sotco Claudius. (2017). Issues in Financing Higher Education in Tanzania The Future of Accessibility in International Higher Education (pp. 125-138): IGI Global. 
26. Laosa, LM. (2005). Effects of preschool on educational achievement (NIEER Working Paper). New Brunswick, NJ: National Institute for Early Education Research, Rutgers University.

27. Marcucci, P, \& Johnstone, B. (2003). Tuition policies in a comparative perspective: Theoretical and political rationales. Paper presented at the 28th Annual Conference of the American Education Finance Association.

28. McMahon, Walter W. (2009). Higher learning, greater good: The private and social benefits of higher education: JHU Press.

29. Memba, Albert Zephaniah, \& Feng, Zhao Zun. (2016). Performance of the Higher Education Students Loans Board in Human Capital Investment from 2005-2015. Higher Education Studies, 6 (3), 48.

30. Mohamedbhai, Goolam. (2014). Massification in higher education institutions in Africa: Causes, consequences and responses. International Journal of African Higher Education, 1 (1).

31. Mpiza, Maua. (2007). The impacts of cost sharing on students in public universities in Tanzania: a case study of The University of Dar es Salaam.

32. Msigwa, Faustina Martha. (2016). Widening participation in higher education for students from the low socio-economic status group? A social justice analysis of student loans in Tanzania. University of Bristol.

33. Odebero, Stephen O, Bosire, Joseph N, Sang, Anthony K, Ngala, Fredrick BJ, \& Ngware, Moses W. (2007). Equity in the distribution of HELB loans in Kenya in relation to student characteristics: an empirical analysis. Educational Research and Reviews, 2 (8), 209.

34. Orodho, John Aluko. (2014). Policies On Free Primary And Secondary Education In East Africa: Are Kenya And Tanzania On Course To Attain Education For All (Efa) Goals By 2015?

35. Padgett, Deborah K. (2016). Qualitative methods in social work research (Vol. 36): Sage Publications.

36. Pan, Su-Yan. (2013). China's approach to the international market for higher education students: strategies and implications. Journal of Higher Education Policy and Management, 35 (3), 249-263.

37. Paulsen, Michael B. (2001). The economics of human capital and investment in higher education. The finance of higher education: Theory, research, policy, and practice, 55-94.

38. Psacharopoulos, G, Tan, JP, \& Jimenez, E. (1986). Financing Education in Developing Countries (Washington, DC: World Bank). Education and Training Department/Research Division.

39. Puja, Grace Khwaya. (2009). Cost-sharing in higher education in Tanzania: The experiences of the 1990s and one decade later. 
Comparative and International Education/Éducation Comparée et international, 38 (1), 61-76.

40. Rugambuka, Innocent Buberwa. (2008). The performance of higher education students' loan scheme in Tanzania: the stakeholders' views.

41. Sanyal, Bikas C, \& Kinunda, Michael J. (1977). Higher education for self-reliance: The Tanzanian experience: International Institute for Educational Planning.

42. Schendel, Rebecca, \& McCowan, Tristan. (2015). Higher education and development: Critical issues and debates. Education and development: An introduction, 275-293.

43. Schendel, Rebecca, \& McCowan, Tristan. (2016). Expanding higher education systems in low-and middle-income countries: the challenges of equity and quality. Higher Education, 72 (4), 407-411.

44. Shaheen, Faiza, \& Gul, Fariha. (2014). Socioeconomic status and achievement: a survey study of students at secondary level. International Journal of Educational Studies, 1 (3), 163-167.

45. Teixeira, Pedro N, Johnstone, D Bruce, Rosa, Maria J, \& Vossensteyn, Hans. (2006). Cost-sharing and accessibility in higher education: A fairer deal? (Vol. 14): Springer.

46. Wang, Xiaobing, Liu, Chengfang, Zhang, Linxiu, Luo, Renfu, Glauben, Thomas, Shi, Yaojiang, ... Sharbono, Brian. (2011). College education and the poor in China: documenting the hurdles to educational attainment and college matriculation. Asia Pacific Education Review, 12 (4), 533.

47. Wiersma, W, \& Jurs, S. (2009). Research design in quantitative research. Research methods in education: An introduction.

48. Woodhall, Maureen. (1987). Human capital concepts Economics of education (pp. 21-24): Elsevier.

49. Xia, Yan Ruth, Wang, Haiping, Do, Anh, \& Qin, Shen. (2014). Family policy in China: A snapshot of 1950-2010 Handbook of family policies across the globe (pp. 257-272): Springer.

50. Yan, Wang, \& Yudong, Yao. (2003). Sources of China's economic growth 1952-1999: incorporating human capital accumulation. China Economic Review, 14 (1), 32-52.

51. Yang, Rui. (2004). Toward massification: Higher education development in the People's Republic of China since 1949 Higher education: Handbook of theory and research (pp. 311-374): Springer. 